\title{
Adaptation of the Use of Pyroligneous Acid in Control of Caterpillars and Agronomic Performance of the Soybean Crop
}

\author{
F. A. Petter ${ }^{1}$, Luciana B. Silva ${ }^{1}$, Isidoro J. Souza ${ }^{2}$, Kellen Magionni ${ }^{1}$, Leandro P. Pacheco ${ }^{1}$, \\ Fernandes A. Almeida ${ }^{1} \&$ Bruno E. Pavan ${ }^{2}$ \\ ${ }^{1}$ Pós-Graduate Program in Agronomy - Plant Science, Federal University of Piauí - UFPI/CPCE, Bom Jesus - \\ PI, Brazil \\ ${ }^{2}$ Departament of Agronomy, Federal University of Piaú - UFPI/CPCE, Bom Jesus - PI, Brazil \\ Correspondence: Luciana Barboza Silva Campus "Profa. Cinobelina Elvas", BR 135, km 3 - Bairro Planalto \\ Horizonte. CEP: 64900-000. Bom Jesus-PI, Brazil. E-mail: lubarbosabio@hotmail.com
}

Received: April16, 2013 Accepted: June 4, 2013 Online Published: July 15, 2013

doi:10.5539/jas.v5n8p27 URL: http://dx.doi.org/10.5539/jas.v5n8p27

\begin{abstract}
The objective of this study was to evaluate the effect of pyroligneous acid alone and in combination with insecticides in control of caterpillars and on the agronomic performance of soybean. The experiment was conducted under field and laboratory conditions in Bom Jesus - PI, in the 2010/2011 and 2011/2012 crop seasons. The field experiment used in a randomized block, $4 \times 4$ factorial design with four replications, the factors consisting of four pyroligneous acid concentrations (zero, 1.5, 3.0, and 6.0\%) and five insecticide treatments: lambdacyhalothrin + thiamethoxam $\left(15.9 \mathrm{~g} \mathrm{ha}^{-1}+21.15 \mathrm{~g} \mathrm{ha}^{-1}\right)$, cypermethrin $\left(300 \mathrm{~g} \mathrm{ha}^{-1}\right)$, chlorpyriphos $(240 \mathrm{~g}$ $\left.\mathrm{ha}^{-1}\right)$, teflubenzuron $\left(7.5 \mathrm{~g} \mathrm{ha}^{-1}\right)$. In the laboratory a completely randomized design was used with 12 treatments and five replications. We evaluated the control of $A$. gemmatalis and $P$. includens (in field and laboratory), agronomic characteristics and yield. The application of pyroligneous acid alone or in combination with insecticides provided levels of control of $A$. gemmatalis and $P$. includens similar to the insecticides tested. There was no effect of pyroligneous acid on the number of pods plant ${ }^{-1}$ or grains $\operatorname{pod}^{-1}$. The yield was higher than the control, but did not differ from the other treatments containing pyroligneous acid alone or in combination. According to laboratory and field tests, it appears that the pyroligneous extract affected the number of larvae plant ${ }^{-1}$ and reduced leaf consumption, an important result for management programs of $A$. gemmatalis and $P$. includens.
\end{abstract}

Keywords: soybean looper, soybean caterpillar, Biopirol ${ }^{\circledR}$, grain production

\section{Introdution}

The Brazilian Cerrado has distinguished itself in the national scenario as a region with great potential for grain production, principally with soybean, attracting to the region numerous multinational companies in the agricultural defensives sector, as a function of the elevated demand for inputs.

The agricultural defensives sector began the year of 2012 with the expectation of $10 \%$ revenue growth, the consumption of insecticides being responsible for $21 \%$ of the total volume consumed (Sindag, 2012). The growth of the sector is driven by the traditional crops in demand, such as soybean, corn and cotton.

As a result of the difficulty of controlling caterpillars and loss of productivity due to defoliation, producers have used sequential spraying, seeking to avoid an increase in pest population density. In the meantime, there are many questions concerning the most appropriate time for spraying and the most efficient insecticides, seeking the satisfactory control mainly of caterpillars in the subfamily Plusiinae on soybeans. This fact gains distinction, seeing the importance in the national and international scenario of the soybean crop and owing to the population increase in comparison with the soybean caterpillar (Anticarsia gemmatalis) (Guedes et al., 2011).

The increased use of insecticides in soybean, where many times the applications are made indiscriminately, whether at high or low doses, using products often highly toxic to the environment, has led to a series of problems in the management of pests, among them the resistance of the insects to insecticides (Romero et al., 2007; Silva et al., 2011). 
The evolution of pest resistance to pesticides has become one of the greatest obstacles to control programs involving the use of chemical products. The reported cases of resistance intensified with the introduction of organo-synthetic insecticides and miticides around the 1940s (Silva et al., 2011).

With the growth of insect populations resistant to insecticides, especially to the traditional chemical groups, and the interference of these with environment, research has increasingly focused on the search for new chemicals and new molecules of natural origin and less harmful to the environment. One of the products that might be an alternative to control pests in soybeans is pyroligneous acid.

Its qualities have been known for decades in Japan and were disseminated in Brazil by immigrants from that country, especially in meetings of the Association of Natural Agricultural Producers (APAN) (FAPEMIG, 2005), being used as "organic fertilizer" in rice (Oryza sativa L.) (Tsuzuki et al., 2000), sorghum (Sorghum bicolor L.) (Esechie et al., 1998) and sweet potato (Ipomoea batatas L.) (Shibayama et al., 1998), and as a nematicide (Cuadra et al., 2000) and fungicide (Numata et al., 1994). Recently, Petter et al. (2012) found positive effects of pyroligneous acid as a reducer of $\mathrm{pH}$ efficient at stabilizing spray pesticides.

Pyroligneous acid is a product obtained from the pyrolysis of wood, where condensable gases are catalyzed. This product contains about 100 chemicals, including methanol $(0.1 \%$ to $1.0 \%)$, acetone $(0.2 \%)$ and water $(85 \%$ to $90 \%$ ), with predominantly acetic acid (5.0\% to $6.0 \%)$ and $\mathrm{pH}$ between 2.0 and 3.0 (BIOCARBO, 2001).

Not being a marketed product, little information is available in the national literature on studies of pyroligneous acid in the control of major crop pests, thus making it necessary to conduct research in order to adapt its use to generate a new technology for control of these pests, associating efficiency of control with low environmental impact.

There is reason to believe pyroligneous acid may be effective not only as an insecticide but also as a foliar fertilizer and $\mathrm{pH}$ reducer. Therefore, this study aimed to evaluate the effectiveness of pyroligneous acid applied alone and in combination with other insecticides in control of caterpillars and on the agronomic performance of soybean.

\section{Materials and Methods}

\subsection{Field Experiment}

Field experiment was conducted in commercial crop in Bom Jesus-PI in soil classified as dystrophic Yellow Latosol (LAd) and in the laboratory on the campus of the Federal University of Piauí (UFPI) in Bom Jesus-PI $\left(09^{\circ} 04^{\prime} 28^{\prime \prime S}\right.$ South latitude, $44^{\circ} 21^{\prime} 31^{\prime \prime}$ west longitude), between October 2010 to June 2012. The field experiment involved two growing seasons (2010/2011 and 2011/2012).

The sowing of soybean (cultivar Monsoy 9350) was done on November 20, 2010 and December 10, 2011, distributing 13 seeds per meter, with spacing of $0.45 \mathrm{~m}$ between rows and sowing depth of $2-3 \mathrm{~cm}$. N-P $\mathrm{P}_{2} \mathrm{O}_{5}-\mathrm{K}_{2} \mathrm{O}$ fertilizer of the formula 02-20-18 was applied at $400 \mathrm{~kg} \mathrm{ha}^{-1}$.

The experimental design was randomized block, $4 \times 4$ factorial, the factors consisting of four acid concentrations of pyroligneous acid (zero, 1.5, 3.0, and 6.0\%) from the commercial product Biopirol ${ }^{\circledR}$, applied alone and in combination with four insecticide treatments: lambdacyhalothrin + thiamethoxam $\left(15.9 \mathrm{~g} \mathrm{ha}^{-1}+21.15 \mathrm{~g} \mathrm{ha}^{-1}\right)$, cypermethrin $\left(300 \mathrm{~g} \mathrm{ha}^{-1}\right)$, chlorpyriphos $\left(240 \mathrm{~g} \mathrm{ha}^{-1}\right)$, teflubenzuron $\left(7.5 \mathrm{~g} \mathrm{ha}^{-1}\right)$, thus totaling 16 treatments, performed in four replicates.

Each plot consisted of nine lines of crop $5 \mathrm{~m}$ in length, totaling $20.25 \mathrm{~m}^{2}$; the useful area for evaluation was $12.60 \mathrm{~m}^{2}$, once a line on each side of the main plot and $0.5 \mathrm{~m}$ at each end were excluded. Treatments were applied 50 days after crop emergence, using a backpack sprayer pressurized with $\mathrm{CO}_{2}$, the rod being attached to four XR 110.020 spray nozzles, applying a spray volume equivalent to $125 \mathrm{~L} \mathrm{ha}^{-1}$.

At 7, 14 and 28 days after application (DAA) the following evaluations were made: visual crop phytotoxicity, using a percentage scale ranging from 0 to $100 \%$, where zero means no visual symptoms and $100 \%$ the death all soybean plants; soybean caterpillar control, evaluating the number of caterpillars, using the Embrapa (2000) method of three cloth beats/plot.

At soybean harvest, the number of pods per plant and number of seeds per pod were counted, collecting from 20 plants per plot. Later, grain yield was determined with subsequent standardization of grain moisture at $14 \%$, collecting from all plants in the active plot area.

For the field data, combined analysis of variance was evaluated for the two crop seasons, the averages of the significant variables grouped by Tukey test at $5 \%$ significance. 


\subsection{Laboratory Bioassays}

The insect pests used in all the bioassays, Anticarsia gemmatalis and Pseudoplusia includens, were collected in the field. Adults of A. gemmatalis and P. includens were placed in PVC cages $(30 \mathrm{~cm}$ high x $20 \mathrm{~cm}$ diameter) lined with bond paper serving as substrate for oviposition and maintained in a climate-controlled room (temperature: $27 \pm 2^{\circ} \mathrm{C}$, relative humidity: $60 \pm 10 \%$ and photoperiod: 14 hours). Adults were fed with a cotton swab soaked in $10 \%$ honey solution, placed on a petri dish at the bottom of the cage. After the onset of oviposition, eggs were collected every 2 days. The eggs were placed in plastic cups until the emergence of caterpillars, which were transferred to artificial diet proposed by Greene et al. (1976), according to the behavior of each caterpillar.

\subsubsection{Topical Bioassay}

Topical application of pyroligneous acid was made in the third instar larvae of A. gemmatalis and P. includens. Ten $\mu \mathrm{L}$ of solution was applied to each insect on the mesothorax between the second and third pair of legs. This droplet size was chosen to ensure efficient coverage without product loss due to runoff. The pyroligneous acid was diluted with water and applied in concentrations between 0 and $500 \mu \mathrm{L} / \mathrm{mL}$. After application, the larvae were placed in Petri dishes lined with filter paper containing artificial diet and kept in a temperature-controlled room (temperature: $27 \pm 2^{\circ} \mathrm{C}$, relative humidity: $80 \pm 10 \%$ and photoperiod: 14 hours).

The experimental design was a completely randomized design with 12 treatments and 5 replicates, each replicate consisting of 10 insects. The evaluation of the deleterious effects of pyroligneous acid on the insects was based on the following biological parameters: mortality, duration of larval and pupal period, larval and pupal viability, and larval and pupal weight. The laboratory data were submitted to analysis of variance and the means of significant variables grouped by Tukey test at $5 \%$ significance.

\subsubsection{Choice Bioassay}

A. gemmatalis and P. includens on soybean leaves treated with different concentrations of pyroligneous acid: Food preference of $A$. gemmatalis and $P$. includens was evaluated on soybean leaves treated with pyroligneous acid at different concentrations. Leaves of the soybean cultivar Monsoy 9350 were obtained from plants in the V5 stage maintained in pots in a green house. The leaves were washed and immersed in a pyroligneous acid solution for about 5 minutes, subsequently removing excess moisture. Thereafter, discs were cut from along the sides of the leaves, excluding the midrib, with the aid of a punch $5 \mathrm{~cm}$ in diameter. The leaf area of the disks was then measured in $\mathrm{cm}^{2}$, making use of a leaf area meter (Portable LI-COR model LI-3000 A).

After measurement the discs were transferred to Petri dishes containing plaster and lined with moistened filter paper. The plaster served as a base to fix the leaf discs with pins, while the moistened filter paper prevented the drying of leaf tissue. On each plate four discs were placed, a control and three concentrations of pyroligneous acid, equidistant from a central point, where a 4th instar caterpillar of $A$. gemmatalis or $P$. includens raised on artificial diet (Greene et al., 1976) was released. Five replicates were performed. The plates were covered and sealed with adhesive PVC film.

The evaluation was performed 48 hours after release of larvae, and leftover food was again measured in $\mathrm{cm}^{2}$ with the help of leaf area meter. The leaf area consumed was obtained by subtracting the final area of the unconsumed discs from the starting area. Preference indices were calculated by the method of Kogan and Goeden (1970), using the formula:

$$
\mathrm{C}=2 \mathrm{a} /(\mathrm{M}+\mathrm{A})
$$

where:

$\mathrm{C}=$ Preference index

$\mathrm{A}=$ consumption of test plant

$\mathrm{M}=$ consumption of standard plant

The interpretation of the results was in accordance with the value of $\mathrm{C}$ obtained, namely:

$\mathrm{C}>1$ test plant was preferred by the insect relative to the standard plant;

$\mathrm{C}=1$ plant test is similar to the standard plant in terms of preference;

$\mathrm{C}<1$ test plant is less suitable than a standard plant.

The experimental design was fully randomized. The results were submitted to analysis of variance and means were compared by Tukey test at $5 \%$ significance. 


\section{Results and Discussion}

The control of A. gemmatalis was significantly influenced by the treatments, with a significant interaction of the insecticide and pyroligneous acid factors in all periods (Table 1). As for the control of $P$. includes, effect was observed only at 14 days after application (DAA). With the exception of productivity, the yield components number of pods per plant and number of seeds per pod were not affected by the treatments.

Table 1. Analysis of variance (F values) combined for the effect of the different insecticides, pyroligneous acid doses and crop seasons on control of caterpillars, yield components and soybean productivity. Bom Jesus - PI, 2010/2011 and 2011/2012 crops

\begin{tabular}{|c|c|c|c|c|c|c|}
\hline \multirow[t]{2}{*}{ Sources of variance } & \multicolumn{3}{|c|}{$\begin{array}{l}\text { No. Individuals } \\
\text { Anticarsia gemmatalis }\end{array}$} & \multicolumn{3}{|c|}{$\begin{array}{l}\text { No. Individuals } \\
\text { Pseudoplusia includens }\end{array}$} \\
\hline & $7 \mathrm{DAA}$ & $14 \mathrm{DAA}$ & $28 \mathrm{DAA}$ & 7 DAA & $14 \mathrm{DAA}$ & 28 DAA \\
\hline Insecticides (I) & $2.20^{\mathrm{ns}}$ & $1.57^{\mathrm{ns}}$ & $43.1 * *$ & $0.69^{\mathrm{ns}}$ & $2.03^{\mathrm{ns}}$ & $1.37^{\mathrm{ns}}$ \\
\hline Pyroligneous Acid (AP) & $0.27^{\mathrm{ns}}$ & $2.14^{\mathrm{ns}}$ & $34.66^{* *}$ & $0.25^{\mathrm{ns}}$ & $0.74^{\mathrm{ns}}$ & $1.26^{\mathrm{ns}}$ \\
\hline Crop (S) & $0.21^{\mathrm{ns}}$ & $0.32^{\mathrm{ns}}$ & $0.42^{\mathrm{ns}}$ & $0.06^{\mathrm{ns}}$ & $0.08^{\mathrm{ns}}$ & $0.07^{\mathrm{ns}}$ \\
\hline Insecticide x Pyroligneous Acid & $1.76^{*}$ & $4.66^{* *}$ & $34.66^{* *}$ & $0.88^{\mathrm{ns}}$ & $1.84 *$ & $0.63^{\mathrm{ns}}$ \\
\hline Insecticide $\mathrm{x}$ Crops & $0.03^{\mathrm{ns}}$ & $0.02^{\mathrm{ns}}$ & $1.2^{\mathrm{ns}}$ & $0.05^{\mathrm{ns}}$ & $0.02^{\mathrm{ns}}$ & $0.03^{\mathrm{ns}}$ \\
\hline Pyroligneous Acid x Crops & $0.03^{\mathrm{ns}}$ & $0.02^{\mathrm{ns}}$ & $1.3^{\mathrm{ns}}$ & $0.03^{\mathrm{ns}}$ & $0.01^{\mathrm{ns}}$ & $0.02^{\mathrm{ns}}$ \\
\hline $\mathrm{I} x \mathrm{AP} \times \mathrm{S}$ & $0.04^{\mathrm{ns}}$ & $0.03^{\mathrm{ns}}$ & $1.5^{\mathrm{ns}}$ & $0.04^{\mathrm{ns}}$ & $0.03^{\mathrm{ns}}$ & $0.04^{\mathrm{ns}}$ \\
\hline \multirow[t]{2}{*}{ C.V. } & 27.9 & 24.0 & 7.70 & 12.7 & 16.3 & 14.4 \\
\hline & \multicolumn{2}{|c|}{ No. pods plant ${ }^{-1}$} & \multicolumn{2}{|c|}{ No. grains pod ${ }^{-1}$} & \multicolumn{2}{|c|}{ Yield } \\
\hline Insecticides (I) & \multicolumn{2}{|l|}{$1.41^{\mathrm{ns}}$} & \multicolumn{2}{|c|}{$0.71^{\mathrm{ns}}$} & \multicolumn{2}{|c|}{$0.80^{\mathrm{ns}}$} \\
\hline Pyroligneous Acid (AP) & \multicolumn{2}{|l|}{$1.68^{\mathrm{ns}}$} & \multicolumn{2}{|c|}{$0.21^{\mathrm{ns}}$} & \multicolumn{2}{|c|}{$2.16^{\mathrm{ns}}$} \\
\hline Crop (S) & \multicolumn{2}{|l|}{$0.41^{\mathrm{ns}}$} & \multicolumn{2}{|c|}{$0.32^{\mathrm{ns}}$} & \multicolumn{2}{|c|}{$0.23^{\mathrm{ns}}$} \\
\hline Insecticide x Pyroligneous Acid & \multicolumn{2}{|l|}{$0.50^{\mathrm{ns}}$} & \multicolumn{2}{|c|}{$0.28^{\mathrm{ns}}$} & \multicolumn{2}{|c|}{$2.39 *$} \\
\hline Insecticide x Crops & \multicolumn{2}{|l|}{$0.32^{\mathrm{ns}}$} & \multicolumn{2}{|c|}{$0.30^{\mathrm{ns}}$} & \multicolumn{2}{|c|}{$0.24^{\mathrm{ns}}$} \\
\hline Pyroligneous Acid x Crops & \multicolumn{2}{|l|}{$0.25^{\mathrm{ns}}$} & \multicolumn{2}{|c|}{$0.41^{\mathrm{ns}}$} & \multicolumn{2}{|c|}{$0.34^{\mathrm{ns}}$} \\
\hline I x AP x S & \multicolumn{2}{|l|}{$0.31^{\mathrm{ns}}$} & \multicolumn{2}{|c|}{$0.32^{\text {ns }}$} & 0.4 & \\
\hline C.V. & 15.4 & & & & 13 & \\
\hline
\end{tabular}

* e ** significant at 5 and $1 \%$ respectively; ${ }^{\mathrm{ns}}$ - not significant. DAA - Days after application of treatments. C.V. - Coefficient of variation. Crop seasons: 2010/2011 and 2011/2012.

At 7 DAA only the treatment composed of the mixture of cypermethrin and $6 \%$ pyroligneous acid presented lesser control of $A$. gemmatalis (Table 2). Already at 14 and 28 DAA, with the exception of the without insecticide treatment and in the absence of pyroligneous acid that had the worst control, the other treatments did not differ statistically among themselves, thus proving the efficiency of insecticides and pyroligneous acid in the control of $A$. gemmatalis. It is interesting to note the residual effect of pyroligneous acid over the 28 days of evaluation, which kept the infestation within the level of economic injury for this pest. These data differ from those found by Bogorni et al. (2008), who found no effect of the pyroligneous extract in control of Tuta absoluta (tomato pinworm). Importantly, the cited work was developed in the laboratory, and under field conditions the data could differ, as is the case in this work. 
Table 2. Number of individuals of Anticarsia gemmatalis from three cloth beats, after applying combinations of insecticides and pyroligneous acid concentrations. Bom Jesus - PI, 2010/2011 and 2011/2012 crops

\begin{tabular}{|c|c|c|c|c|c|c|}
\hline \multirow[b]{2}{*}{ Insecticides } & & \multicolumn{4}{|c|}{ Pyroligneous Acid (\%) } & \multirow{2}{*}{ Average } \\
\hline & & 0 & 1.5 & 3.0 & 6.0 & \\
\hline & & \multicolumn{4}{|c|}{$7 \mathrm{DAA}^{*}$} & \\
\hline lambdacyhalothrin & + thiamethoxam & $6 \mathrm{aA}$ & $4 \mathrm{aA}$ & $4 \mathrm{aA}$ & $2 \mathrm{aA}$ & 4 \\
\hline cypermethrin & & $4 \mathrm{aA}$ & $5 \mathrm{aA}$ & $5 \mathrm{aA}$ & $8 \mathrm{aB}$ & 6 \\
\hline chlorpyriphos & & $3 \mathrm{aA}$ & $6 \mathrm{aA}$ & $5 \mathrm{aA}$ & $1 \mathrm{aA}$ & 4 \\
\hline teflubenzuron & & $3 \mathrm{aA}$ & $3 \mathrm{aA}$ & $2 \mathrm{aA}$ & $4 \mathrm{aAB}$ & 3 \\
\hline without insecticide & & $6 \mathrm{aA}$ & $4 \mathrm{aA}$ & $2 \mathrm{aA}$ & $6 \mathrm{aAB}$ & 4 \\
\hline \multicolumn{2}{|l|}{ Average } & 4 & 4 & 4 & 4 & 4 \\
\hline & & \multicolumn{4}{|c|}{14 DAA } & \\
\hline lambdacyhalothrin & + thiamethoxam & $0 \mathrm{aA}$ & $1 \mathrm{aA}$ & $1 \mathrm{aA}$ & $1 \mathrm{aA}$ & 1 \\
\hline cypermethrin & & $1 \mathrm{aA}$ & $1 \mathrm{aA}$ & $0 \mathrm{aA}$ & $0 \mathrm{aA}$ & 1 \\
\hline chlorpyriphos & & $1 \mathrm{aA}$ & $1 \mathrm{aA}$ & $1 \mathrm{aA}$ & $0 \mathrm{aA}$ & 1 \\
\hline teflubenzuron & & $0 \mathrm{aA}$ & $0 \mathrm{aA}$ & $0 \mathrm{aA}$ & $0 \mathrm{aA}$ & 0 \\
\hline without insecticide & & $4 \mathrm{bB}$ & $1 \mathrm{aA}$ & $1 \mathrm{aA}$ & $1 \mathrm{aA}$ & 2 \\
\hline \multirow{2}{*}{\multicolumn{2}{|c|}{ Average }} & 1 & 1 & 1 & 1 & 1 \\
\hline & & \multicolumn{4}{|c|}{$28 \mathrm{DAA}$} & \\
\hline lambdacyhalothrin & + thiamethoxam & $0 \mathrm{aA}$ & $0 \mathrm{aA}$ & $0 \mathrm{aA}$ & $0 \mathrm{aA}$ & 0 \\
\hline cypermethrin & & $0 \mathrm{aA}$ & $0 \mathrm{aA}$ & $0 \mathrm{aA}$ & $0 \mathrm{aA}$ & 0 \\
\hline chlorpyriphos & & $0 \mathrm{aA}$ & $0 \mathrm{aA}$ & $0 \mathrm{aA}$ & $0 \mathrm{aA}$ & 0 \\
\hline teflubenzuron & & $0 \mathrm{aA}$ & $0 \mathrm{aA}$ & $0 \mathrm{aA}$ & $0 \mathrm{aA}$ & 0 \\
\hline without insecticide & & $5 \mathrm{bB}$ & $0 \mathrm{aA}$ & $0 \mathrm{aA}$ & $0 \mathrm{aA}$ & 1 \\
\hline Average & & 1 & 0 & 0 & 0 & 1 \\
\hline
\end{tabular}

Averages followed by the same small letters in the line (horizontal) and large letters in the column (vertical) did not differ statistically by Tukey test at $5 \%$ probability. *Days after application.

As reported by Tsuzuki et al. (2000), under field conditions the application of pyroligneous acid can activate substances of plant secondary metabolism, inducing resistance to pests. Therefore, the effect of pyroligneous acid in the control of $A$. gemmatalis may be linked to the synthesis of metabolites involved in the mechanism of plant defense, since, in addition to the pyroligneous extract presenting in its composition phenolic compounds, it presents in larger part as a constituent acetic acid, which is part of the mevalonic acid biosynthetic pathway, a precursor in the synthesis of terpenes, which are essential metabolites in the defense mechanisms of plants against attack by herbivorous insects. Campos et al. (2005) found greater accumulation of phenolic compounds after application of pyroligneous acid. It is important to emphasize also that terpenes in the form of monomers, called pyrethroids, have insecticidal activity.

For the control of $P$. includens treatment effect was seen only at 14 DAA; cypermethrin was the treatment that showed the lowest rates of control (Table 3). These results differ from those of Morandi Filho et al. (2006), who found no effect of pyroligneous extract on Argyrotaenia sphaleropa in the laboratory, but corroborate those of Azevedo et al. (2005), who reported on the effect of field application of pyroligneous acid in control of Bemisia tabaci. 
Table 3. Number of individuals of Pseudoplusia includens, from three beats of cloth, after applying combinations of insecticides and pyroligneous acid concentrations. Bom Jesus - PI, 2010/2011 and 2011/2012 crops

\begin{tabular}{|c|c|c|c|c|c|c|}
\hline \multirow{2}{*}{ Insecticides } & & \multicolumn{4}{|c|}{ Pyroligneous Acid (\%) } & \multirow{2}{*}{ Average } \\
\hline & & 0 & 1,5 & 3,0 & 6,0 & \\
\hline & & \multicolumn{4}{|l|}{$7 \mathrm{DAA}^{*}$} & \\
\hline lambdacyhalothrin & + thiamethoxam & 31 & 43 & 42 & 40 & $39^{\text {ns }}$ \\
\hline cypermethrin & & 34 & 40 & 40 & 36 & 37 \\
\hline chlorpyriphos & & 32 & 35 & 35 & 39 & 35 \\
\hline teflubenzuron & & 47 & 41 & 34 & 43 & 41 \\
\hline without insecticide & & 43 & 40 & 41 & 34 & 40 \\
\hline \multirow{2}{*}{\multicolumn{2}{|c|}{ Average }} & 37 & 40 & 38 & 38 & 38 \\
\hline & & \multicolumn{4}{|l|}{14 DAA } & \\
\hline lambdacyhalothrin & + thiamethoxam & $11 \mathrm{aA}$ & $8 \mathrm{aA}$ & $12 \mathrm{aA}$ & $16 \mathrm{aA}$ & 12 \\
\hline cypermethrin & & $13 \mathrm{abA}$ & $20 \mathrm{bB}$ & $16 \mathrm{abA}$ & $10 \mathrm{aA}$ & 15 \\
\hline chlorpyriphos & & $14 \mathrm{aA}$ & $17 \mathrm{aAB}$ & $17 \mathrm{aA}$ & $14 \mathrm{aA}$ & 16 \\
\hline teflubenzuron & & $9 \mathrm{aA}$ & $12 \mathrm{aAB}$ & $17 \mathrm{aA}$ & $11 \mathrm{aA}$ & 12 \\
\hline without insecticide & & $20 \mathrm{bA}$ & $1 \mathrm{aAB}$ & $12 \mathrm{aA}$ & $12 \mathrm{aA}$ & 14 \\
\hline \multirow{2}{*}{\multicolumn{2}{|c|}{ Average }} & 14 & 14 & 15 & 13 & 14 \\
\hline & & \multicolumn{4}{|l|}{28 DAA } & \\
\hline lambdacyhalothrin & + thiamethoxam & 10 & 9 & 9 & 6 & $8^{\mathrm{ns}}$ \\
\hline cypermethrin & & 10 & 9 & 10 & 10 & 10 \\
\hline chlorpyriphos & & 12 & 10 & 9 & 11 & 11 \\
\hline teflubenzuron & & 9 & 9 & 8 & 10 & 9 \\
\hline without insecticide & & 13 & 8 & 8 & 8 & 9 \\
\hline Average & & 11 & 9 & 9 & 9 & 9 \\
\hline
\end{tabular}

Averages followed by the same small letters in the line (horizontal) and large letters in the column (vertical) did not differ statistically by Tukey test at $5 \%$ probability. ${ }^{*}$ Days after application.

It is observed that generally all treatments showed reduced numbers of insects during the trial period. This may be linked to climatic conditions during the experiment, such as the above average rainfall. These conditions led to lower pressure from $P$. includens in the experimental area.

It can be seen that the systemically-acting insecticides in combination with pyroligneous acid showed better control of A. gemmatalis and $P$. includens, which may also be associated with greater absorption of the products, because of a possible coordination complex effect of the acid (formation of chelates) with the insecticide molecules, by electrochemical bonds with the carboxyl and phenolic groups in the extract, which in turn have greater facility of penetration via the cuticle and plasma membrane. According to Zanetti et al. (2004), there is evidence that the pyroligneous extract, due to some physico-chemical characteristics, among them the chelating effect, could enhance the efficiency of pesticides in foliar sprays.

In general, smaller yields were observed in the control and cypermethrin treatment associated with $1.5 \%$ pyroligneous acid (Table 4). This may be associated with loss of leaf area caused by the greater number of individuals of $A$. gemmatalis and $P$. includens, reducing the photosynthetic active area and hence the production of photoassimilates that would be directed to the grain. It is interesting to note that productivity in the absence of pesticides and in the presence of acid pyroligneous was unaffected, demonstrating it to be an alternative to control these pests when applied alone or in combinations with insecticides. 
Table 4. Yield of soybeans after application of combinations of insecticides and pyroligneous acid concentrations. Bom Jesus - PI, 2010/2011 and 2011/2012 crops

\begin{tabular}{llllll}
\hline \multirow{2}{*}{ Insecticides } & \multicolumn{4}{l}{ Pyroligneous Acid (\%) } & \multirow{2}{*}{ Average } \\
\cline { 2 - 5 } & 0 & 1.5 & 3.0 & 6.0 & \\
\cline { 2 - 5 } & $7 \mathrm{DAA}^{*}$ & & & & 3.809 \\
\hline $\begin{array}{l}\text { lambdacyhalothrin } \\
\text { thiamethoxam }\end{array}$ & $3.388 \mathrm{aA}$ & $4.099 \mathrm{aAB}$ & $3.827 \mathrm{aA}$ & $3.925 \mathrm{aA}$ & \\
cypermethrin & $3.544 \mathrm{aA}$ & $3.291 \mathrm{aB}$ & $3.688 \mathrm{aA}$ & $3.902 \mathrm{aA}$ & 3.606 \\
chlorpyriphos & $3.555 \mathrm{aA}$ & $3.761 \mathrm{aAB}$ & $3.402 \mathrm{aA}$ & $3.419 \mathrm{aA}$ & 3.534 \\
teflubenzuron & $3.847 \mathrm{abA}$ & $4.311 \mathrm{aA}$ & $3.363 \mathrm{bA}$ & $4.013 \mathrm{abA}$ & 3.883 \\
without insecticide & $3.055 \mathrm{aB}$ & $3.847 \mathrm{aAB}$ & $3.958 \mathrm{aA}$ & $3.519 \mathrm{aA}$ & 3.594 \\
Average & 3.477 & 3.861 & 3.647 & 3.755 & 3.685 \\
\hline
\end{tabular}

Averages followed by the same small letters in the line (horizontal) and large letters in the column (vertical) did not differ statistically by Tukey test at $5 \%$ probability. *Days after application.

There was no correlation between the components of production, number of pods plant ${ }^{-1}$ and number of grains $\operatorname{pod}^{-1}$, with productivity. Studies show that variables such as number of pods plant ${ }^{-1}$ and number of grains pod ${ }^{-1}$ may not correlate with production (Stone \& Moreira, 2000; Oliveira et al., 2002), due to the unevenness in the stand as well as to production components such as radiation, that are difficult to measure, leading to high coefficients of variation.

The values obtained for the duration of the larval stage of $A$. gemmatalis treated topically with different concentrations of pyroligneous acid did not differ significantly (Table 5). The data on the average duration of the larval phase were similar to those reported by Gazzoni \& Tutida (1996), who obtained 13.7 days, and Machado et al. (1999), who obtained 14.8 days. In bioassays with $P$. includens, the larval period increased with increasing concentrations of pyroligneous acid. There was an adverse effect on the biology of the insect that required a greater number of days to complete the larval stage. The pupal period for both $A$. gemmatalis as for P. includens did not differ from control. The weight of the larvae of A. gemmatalis was lower at higher concentrations of pyroligneous acid, which did not affect the duration of the larval period, but affected the metabolic development because it reduced the weight of pupae of $A$. gemmatalis and $P$. includens (Table 5), which is directly related to the biotic potential. In topical application, concentrations exceeding $200 \mu \mathrm{L} / \mathrm{mL}$ were associated with mortality before the insects completed the cycle, thus no data are displayed in the table.

Table 5. Average duration (days), weight (mg) and viability (\%) of the larval and pupal phases of Anticarsia gemmatalis and Pseudoplusia includens submitted to topical treatment with pyroligneous acid. Temperature: $27 \pm 2{ }^{\circ} \mathrm{C}$, relative humidity: $60 \pm 10 \%$, photophase: $14 \mathrm{~h}$

\begin{tabular}{|c|c|c|c|c|c|c|c|c|c|c|c|c|}
\hline & \multicolumn{2}{|c|}{$\begin{array}{l}\text { Duration of Larval } \\
\text { Period (Days) }\end{array}$} & \multicolumn{2}{|c|}{$\begin{array}{l}\text { Duration of Pupal Period } \\
\text { (Days) }\end{array}$} & \multicolumn{2}{|c|}{ Larval Weight (mg) ${ }^{2}$} & \multicolumn{2}{|c|}{ Pupal Weight (mg) ${ }^{2}$} & \multicolumn{2}{|c|}{ Larval Viability (\%) } & \multicolumn{2}{|c|}{ Pupal Viability ( \%) } \\
\hline & $\begin{array}{l}\text { Anticarsia } \\
\text { gemmatalis }\end{array}$ & $\begin{array}{l}\text { Pseudoplusi } \\
\text { a includens }\end{array}$ & $\begin{array}{l}\text { Anticarsia } \\
\text { gemmatalis }\end{array}$ & $\begin{array}{l}\text { Pseudoplusi } \\
\text { a includens }\end{array}$ & $\begin{array}{l}\text { Anticarsia } \\
\text { gemmatalis }\end{array}$ & $\begin{array}{l}\text { Pseudoplusi } \\
\text { a includens }\end{array}$ & $\begin{array}{l}\text { Anticarsia } \\
\text { gemmatalis }\end{array}$ & $\begin{array}{l}\text { Pseudoplusi } \\
\text { a includens }\end{array}$ & $\begin{array}{l}\text { Anticarsia } \\
\text { gemmatalis }\end{array}$ & $\begin{array}{l}\text { Pseudoplusi } \\
\text { a includens }\end{array}$ & $\begin{array}{l}\text { Anticarsia } \\
\text { gemmatalis }\end{array}$ & $\begin{array}{l}\text { Pseudoplusi } \\
\text { a includens }\end{array}$ \\
\hline $\begin{array}{l}\text { Source of } \\
\text { Variation }\end{array}$ & \multicolumn{12}{|c|}{ Mean squares } \\
\hline $\begin{array}{l}\text { Treatmen } \\
\text { ts }\end{array}$ & $7.713^{* *}$ & $11.333 * *$ & $0.54 \mathrm{~ns}$ & $0.853 \mathrm{~ns}$ & $7606.64 * *$ & $0.00070 \mathrm{~ns}$ & $8724.23 * *$ & $0.00893^{* *}$ & $2051.33 * *$ & $4382 * *$ & $1427.12 * *$ & $3040.244 * *$ \\
\hline error & 0.8666 & 1.8667 & 0.90 & 0.9667 & 730.73 & 0.000342 & 113.28333 & 0.0006898 & 118.33333 & 190 & 228.67961 & 399.59952 \\
\hline $\mathrm{CV} \%$ & 6.9301 & 7.6612 & 12.32 & 13.0512 & 10.7783 & 26.84700 & 7.671887 & 16.13931 & 13.65453 & 19.9769 & 21.18394 & 32.64577 \\
\hline $\begin{array}{l}\text { Treatmen } \\
\text { ts } \mu \mathrm{L} / \mathrm{mL}\end{array}$ & \multicolumn{12}{|c|}{ Averages $^{1}$} \\
\hline 200 & $14.2 \mathrm{a}$ & $19.6 \mathrm{a}$ & $7.8 \mathrm{a}$ & $7.8 \mathrm{a}$ & $206.8 \mathrm{~b}$ & $0.049 \mathrm{a}$ & $123.2 \mathrm{~b}$ & $0.122 b$ & $52 \mathrm{c}$ & $32 \mathrm{c}$ & $41.6 \mathrm{~b}$ & $18.7 \mathrm{~b}$ \\
\hline 120 & $15.0 \mathrm{a}$ & $19.2 \mathrm{a}$ & $8.2 \mathrm{a}$ & $8.2 \mathrm{a}$ & $227.0 \mathrm{~b}$ & $0.066 \mathrm{a}$ & $111.4 \mathrm{~b}$ & $0.138 \mathrm{~b}$ & $60 \mathrm{c}$ & $40 \mathrm{c}$ & $65.1 \mathrm{a}$ & $48.7 \mathrm{a}$ \\
\hline 70 & $14.4 \mathrm{a}$ & $18.6 \mathrm{ab}$ & $7.8 \mathrm{a}$ & $7.2 \mathrm{a}$ & $216.4 b$ & $0.064 \mathrm{a}$ & $107.2 \mathrm{~b}$ & $0.150 \mathrm{~b}$ & $78 \mathrm{~b}$ & $60 \mathrm{~b}$ & $74.2 \mathrm{a}$ & $60.6 \mathrm{a}$ \\
\hline 50 & $12.2 \mathrm{a}$ & $17.0 \mathrm{bc}$ & $7.6 \mathrm{a}$ & $7.6 \mathrm{a}$ & $287.8 \mathrm{a}$ & $0.075 \mathrm{a}$ & $106.4 \mathrm{~b}$ & $0.140 \mathrm{~b}$ & $88 \mathrm{ab}$ & $82 \mathrm{a}$ & $73.4 \mathrm{a}$ & $75.4 \mathrm{a}$ \\
\hline 10 & $12.6 \mathrm{a}$ & $16.8 \mathrm{bc}$ & $7.6 \mathrm{a}$ & $7.2 \mathrm{a}$ & $298.0 \mathrm{a}$ & $0.080 \mathrm{a}$ & $192.2 \mathrm{a}$ & $0.204 a$ & $100 \mathrm{a}$ & $100 \mathrm{a}$ & $86.0 \mathrm{a}$ & $80.0 \mathrm{a}$ \\
\hline 0 & $12.2 \mathrm{a}$ & $15.8 \mathrm{c}$ & $7.2 \mathrm{a}$ & $7.2 \mathrm{a}$ & $268.8 \mathrm{a}$ & $0.079 \mathrm{a}$ & $192.0 \mathrm{a}$ & $0.222 \mathrm{a}$ & $100 \mathrm{a}$ & $100 \mathrm{a}$ & $88.0 \mathrm{a}$ & $84.0 \mathrm{a}$ \\
\hline
\end{tabular}

${ }^{1}$ Averages followed by the same letter in the columns do not different among themselves by Tukey test at $5 \%$.

${ }^{2}$ Transformed data in $\sqrt{x}+0.5$. 
The viability of the larval stage for the six treatments was significantly reduced with increasing concentrations. It was observed that the caterpillars had a small body size in relation to days of life, although no abnormalities were observed. The number to instars was similar for all treatments, with five instars for both A. gemmatalis and P. includens (Table 5).

In the multiple choice test, treatment of soybean leaves with different concentrations of pyroligneous acid reduced consumption of leaf area over 48 hours, resulting in a lower preference index and explaining the data collected in the field trials, where the pyroligneous extract alone or in combination reduced the number of larvae during the trial period. At concentrations above $260 \mathrm{~mL} / \mathrm{ml}$ there was no consumption as a function of larval mortality. Thus it can be inferred that pyroligneous extract has a contact and ingestion effect.

Table 6. Consumed leaf area $\left(\mathrm{cm}^{2}\right)$ and Preference Index for $4^{\text {th }}$ instar larvae of Anticarsia gemmatalis and Pseudoplusia includens within 48 hours in free choice test of soybean leaves treated with different concentrations of pyroligneous acid. Temperature: $27 \pm 2{ }^{\circ} \mathrm{C}, \mathrm{RH} 60 \pm 10 \%$, photophase: $14 \mathrm{~h}$

\begin{tabular}{|c|c|c|c|c|}
\hline & \multicolumn{2}{|l|}{ Foliar Consumption $\mathrm{cm}^{2}$} & \multicolumn{2}{|l|}{ Preference Index } \\
\hline & Anticarsia gemmatalis & Pseudoplusia includens & Anticarsia gemmatalis & Pseudoplusia includens \\
\hline Source of Variation & Mean squares & & & \\
\hline Treatments & 8.035 & 2.9088 & 2.908 & 0.4510 \\
\hline error & 0.2365 & 0.132 & 0.132 & 0.0064 \\
\hline $\mathrm{CV} \%$ & 20.860 & 42.908 & 42.908 & 17.811 \\
\hline Treatments $\mu \mathrm{L} / \mathrm{mL}$ & Averages $^{1}$ & & & \\
\hline 0 & $4.12 \mathrm{a}$ & $2.46 \mathrm{a}$ & $1 \mathrm{a}$ & $1 \mathrm{a}$ \\
\hline 10 & $3.28 b$ & $1.32 \mathrm{~b}$ & $0.88 \mathrm{ab}$ & $0.69 b$ \\
\hline 50 & $3.09 \mathrm{~b}$ & $0.88 \mathrm{bc}$ & $0.85 \mathrm{ab}$ & $0.52 \mathrm{c}$ \\
\hline 70 & $2.76 b$ & $0.80 \mathrm{bc}$ & $0.79 b$ & $0.49 \mathrm{c}$ \\
\hline 120 & $2.01 \mathrm{c}$ & $0.6 \mathrm{~cd}$ & $0.64 c$ & $0.42 \mathrm{c}$ \\
\hline 200 & $1.76 \mathrm{c}$ & $0.30 \mathrm{~cd}$ & $0.59 \mathrm{c}$ & $0.21 \mathrm{~d}$ \\
\hline 260 & $1.60 \mathrm{c}$ & $0.21 \mathrm{~cd}$ & $0.55 \mathrm{c}$ & $0.15 \mathrm{~d}$ \\
\hline 300 & $0 \mathrm{~d}$ & $0.13 \mathrm{~d}$ & $0 \mathrm{~d}$ & $0.09 \mathrm{~d}$ \\
\hline
\end{tabular}

Averages followed by different letters in the column differ significantly among themselves by Tukey test at $5 \%$.

The literature regarding the use and efficiency of pyroligneous extract as insecticide is still limited. Thuller et al. (2007) report larval mortality for Plutella xyslostella, Biopirol was effective at control under the conditions tested. Silva et al. $(2005,2006)$ found a toxic effect of pyroligneous extract on Atta sexdens rubropilosa, noting that pyroligneous extract was associated with ant mortality lasting up to five days after application and eucalyptus seedlings treated by spraying and immersion in pyroligneous extract between $0.1 \%$ and $0.2 \%$ inhibited foraging activity of Atta sexdens rubropilosa. Also Azevedo et al. (2005) reported that pyroligneous extract increases the effectiveness of nymph control throughout plant development and reduces the effect in the control of adults at the end of the cycle. Etoffel Efron et al. (2011a) found that pyroligneous acid under the conditions tested did not have a negative effect on the survival of adult Cryptolaemus montrouzieri, demonstrating that the products are selective for this species. Also Etoffel Efron et al. (2011b) did not identify insecticidal activity of pyroligneous extract on Anastrepha fraterculus under the conditions tested. Mendonça et al. (2006), in investigating the effect of pyroligneous acid on Leocoptera coffeella, noted there is no negative effect on the predatory wasp of the pest. According to Peter et al. (2012) pyroligneous extract was not effective at controlling white spot in maize.

Miyasaka, Ohkawara and Utsumi (1999) found that pyroligneous extract mixed with extracts of garlic, mucuna pepper and neem is effective in controlling pests, when diluted and sprayed on the shoots of plants, making them more vigorous and improving product quality, consistent with the finding of this investigation. In both field and laboratory trials, the pyroligneous extract negatively affected the development of $A$. gemmatalis and $P$. includens and did not reduce soybean yield in the absence of insecticide and presence of pyroligneous extract.

The use of chemical products to control pests is a relevant issue since it has implications for the cost of agricultural production, rural worker safety and environmental risks. Investigations regarding the effectiveness 
of products in pest control, in preliminary laboratory tests or in field trials are very important. They should be performed and discussed constantly in order to avoid control failures, financial losses and negative impact on the system.

This present study addresses with initial field and laboratory testing of the use of pyroligneous extract for control of major agricultural pests of soybean, obtaining positive results in the control of $A$. gemmatalis and $P$. includens. However, it is necessary to continue the investigations as to the dose response curves, impact on beneficial organisms, soil residual effect and mechanism of action.

\section{Acknowledgments}

The Banco do Nordeste do Brasil for financial support to the project registered under the number 3160 of the notice Etene/Fundeci 09/2010.

\section{References}

Alves, M., Cazzeta, J. O., Nunes, M. A., Oliveira, A. L., \& Colombi, C. A. (2007). Ação de diferentes preparações de extrato pirolenhoso sobre Brevipalpus phoenicis (geijskes). Revista Brasileira Fruticultura, $29,2$. http://dx.doi.org/10.1590/S0100-29452007000200037

Azevedo, F. R., Guimarães, J. A., Braga Sobrinho, R., \& Lima, M. A. A. (2005). Eficiência de produtos naturais para o controle de Bemisia tabaci biótipo B (Hemiptera: Aleyrodidae) em meloeiro. Arquivos do Instituto Biológico, 72, 73-79.

Biocarbo Indústria E Comércio. (2001). Biopirol: extrato pirolenhoso. Itabirito: 10p. (Informações Técnicas).

Bogorni, P. C., Pansiera, V. C., Vendramini, J. D., Ribeiro, L. P., Gonçalves-Gervásio, R. C. R., \& Brito, J. O. (2008). Avaliação do efeito do ácido pirolenhoso de três espécies arbóreas sobre Tuta absoluta (Meyrick) (Lepidoptera: Gelechiidae). Bioikos, 22, 109-115.

Campos, A. D., Antunes, L. E. C., Fortes, J., \& Osório, V. A. (2005). Potencial do extrato de Cymbopongon citratus e extrato pirolenhoso para induzir resistência do morangueiro. Hortifruticultura, 10. 2005, Montevideo. Montevideo: Sociedad Uruguya Hortifruticultura. 1 CD-ROM.

Cuadra, R., Cruz, X., Perera, E., Martin, E., \& Diaz, A. (2000). Algunos compuestos naturales com efecto nematicida. Revista de Protección Vegetal, La Habana, 24, 31-37.

Efrom, C. F. S., Redaelli, L. R., Meirelles, R. N., \& Ourique, C. B. (2011). Selectivity of phytosanitary products used in organic farming on adult of Cryptolaemus montrouzieri (Coleoptera, Coccinellidae) under laboratory conditions. Semina: Ciências Agrárias, 32(4), 1429-1438.

Esechie, H. A., Dhaliwal, G. S., Arora, R., Randhawa, N. S., \& Dhawan, A. K. (1998). Assessment of pyroligneous liquid as a potential organic fertilizer. In: Ecological agriculture and sustainable development, 1997, Chandigarh, India. Proceedings. Chandigarh: Center for Research in Rural and Industrial Development, 1, 591-595.

FAPEMIG, Revista Minas faz Ciência. (2005). Disponível em. Retrieved from http://revista.fapemig.br/materia.php?id=182

Guedes, J. V. C., Stecca, C., Dos, S., Rodrigues, R. B., \& Bigolin, M. (2011). Nova dinâmica. Cultivar Grandes Culturas, 139, 24-26.

Miyasaka, S., Ohkawara, T., \& Utsumi, B. (1999). Acido Pirolenhoso: Uso e fabricação. Boletim AgroEcológico, 3,14 dez.

Miyasaka, S., Yazaki, H., Ohkwara, T., Nagai, K., \& Kubota, Y. (2006). Derivados de carvão vegetal, extrato pirolenhoso e fino de carvão na agricultura natural. São Paulo.

Morandi Filho, W. J., Botton, M., Grützmacher, A. D., Giolo, F. P., \& Manzoni, C. G. (2006). Ação de produtos naturaissobre a sobrevivência de Argyrotaenia sphaleropa(Meyrick) (Lepidoptera: Tortricidae) e seletividade deinseticidas utilizados na produção orgânica de videirasobre Trichogramma pretiosum Riley (Hymenoptera: Trichogrammatidae). Ciência $\quad$ Rural, http://dx.doi.org/10.1590/S0103-84782006000400005

Numata, K., Ogawa, T., \& Tanaka, K. (1994). Effects of pyroligneous acid (wood vinegar) on the several soilborne diseases. Proceedings of the Kanto Tosan Plant Protection Society, Omagary, 5, 107-110. 
Oliveira, T. K., Carvalho, G. J., \& Moraes, R. N. S. (2002). Plantas e cobertura e seus efeitos sobre o feijoeiro em plantio direto. Pesquisa Agropecuária Brasileira, Brasília, 37, 1079-1087. http://dx.doi.org/10.1590/S0100-204X2002000800005

Pedro, E. S., Gonçalves, R. M., Meirelles, W. F., \& Paccola-Meirelles, L. D. (2012). Products of different chemical groups to control maize white spot. Semina: Ciências Agrárias, 33, 2981-2984.

Shibayama, H., Mashima, K., Mitsutomi, M., \& Arima, S. (1998). Effects of application of pyroligneous acid solution produced in Karatsu city on growth and free sugar contents of storage roots of sweet potatoes. Marine and Higland Bioscience Center Report, Phukel, 7, 15-23. http://dx.doi.org/10.1590/S0100-29452004000300037

Silva, A. S., Zanetti, R., Carvalho, G. A., \& Mendonça, L. A. (2006). Qualidade de mudas de eucalipto tratadas com extratos pirolenhoso. Cerne, Lavras, 12, 19-26.

Silva, A. S., Zanetti, R., Carvalho, G. A., Santos, A., \& Mattos, J. O. S. (2005). Preferência de formigas cortadeiras por mudas de eucalipto pulverizadas ou imersas em soluções de extrato pirolenhoso em diferentes concentrações. Scientia Forestalis, Piracicaba, 67, 9-13.

Silva, G. A., Picanço, M. C., Bacci, L., Crespo, A. L. B., Rosado, J. F., \& Guedes, R. N. C. (2011). Control failure likelihood and spatial dependence of insecticide resistance in the tomato pinworm, Tuta absoluta. Pest Management Science, 67, 913-920. http://dx.doi.org/10.1002/ps.2131

SINDAG (Sindicato Nacional da Indústria de Produtos para a Defesa Agrícola). (2010). O setor de defensivo agrícolas no Brasil. Retrieved from http://www.sindag.com.br

Stoffel Efrom, C. F., Redaelli, L. R., Meirelles, R. N., \& Ourique, C. B. (2011). Laboratory evaluation of phytosanitary products used for control of the South American fruit fly, Anastrepha fraterculus, in organic farming. Crop Protection, 30, 1162-1167. http://dx.doi.org/10.1016/j.cropro.2011.05.007

Stone, L. F., \& Moreira, J. A. A. (2000). Efeitos de sistemas de preparo do solo no uso da água e na produtividade do feijoeiro. Pesquisa Agropecuária Brasileira, 35, 835-841. http://dx.doi.org/10.1590/S0100-204X2000000400022

Thuler, R, T., De Bortoli, S. A., \& Barbosa, J. C. (2007). Eficácia de inseticidas químicos e produtos vegetais visando ao controle de Plutella xylostella. Cientifica, Jaboticabal, 35, 166-174.

Tsuzuki, E., Morimitsu, T., \& Matsui, T. (2000). Effect of chemical compounds in pyroligneous acid on root growth in rice plant. Journal of Crop Science, 66, 15-16. http://dx.doi.org/10.4025/actasciagron.v34i2.12488

Wanderley, C. S., Faria, R. T., \& Ventura, M. U. (2012). Chemical fertilization, organic fertilization and pyroligneous extract in the development of seedlings of areca bamboo palm (Dypsis lutescens). Acta Scientiarum Agronomy, Maringá, 34, 163-167. http://dx.doi.org/10.4025/actasciagron.v34i2.12488

Zanetti, M., Cazetta, J. O., Júnior, D. M., \& Carvalho, S. A. (2004). Influência do extrato pirolenhoso na calda de pulverização sobre o teor foliar de nutrientes em limoeiro "cravo". Revista Brasileira de Fruticultura, Jaboticabal, 26, 529-533. http://dx.doi.org/10.1590/S0100-29452004000300037

\section{Copyrights}

Copyright for this article is retained by the author(s), with first publication rights granted to the journal.

This is an open-access article distributed under the terms and conditions of the Creative Commons Attribution license (http://creativecommons.org/licenses/by/3.0/). 